\title{
Diagnostika sociálního znevýhodnění žáků v praxi pedagogicko-psychologických poraden
}

\section{Diagnostics of Students' Social Sisadvantage in the Practice of Pedagogical-psychological Counseling Facilities}

Zbyněk Němec ${ }^{1}$, Pedagogická fakulta, Univerzita Karlova, Praha

Tereza Philippová, Pedagogicko-psychologická poradna pro Prahu 3 a 9, Praha

\section{Abstrakt}

Sociální znevýhodněnížáků, v aktuální školské terminologii evidované také pod označením „potřeby podpory vyplývající z odlišných kulturních a životních podmínek“, predstavuje už řadu let diagnosticky obtížně uchopitelný fenomén. Příspěvek zobrazuje výsledky dotazníkového šetření mezi 176 pracovníky školských poradenských zařízení, kteří ve výzkumu reflektovali jak vlastní náhled na problematiku určování sociálního znevýhodnění, tak i sué zkušenosti s diagnostikou tohoto znevýhodnění v praxi pedagogicko-psychologických poraden. Výsledky zřetelně poukazují (mimo jiné i) na přetrvávající nejasnosti ohledně vymezení konceptu sociálního znevýhodnění a na nedostatek nástrojů pro diagnostiku tohoto znevǵhodnění v poradenské praxi.

\section{Klíčová slova}

diagnostika, sociální znevǵhodnění, pedagogicko-psychologická poradna

\section{Abstract}

Students' social disadvantage, in current school terminology also defined as "the need for support resulting from different cultural and living conditions", has been a diagnostically difficult phenomenon for many years. The paper shows the results of a questionnaire survey among 176 employees of school counseling facilities, who in the research reflected both their own insight into the issue of determining social disadvantage and their experience with the diagnostics of this disadvantage in the practice of pedagogical-psychological counseling facilities. The results clearly point to the persisting ambiguities in the definition of the concept of social disadvantage and to the lack of tools for diagnosing this disadvantage in counseling practice.

\section{Keywords}

diagnostics, social disadvantage, pedagogical-psychological counseling facilities

\section{Úvod}

Sociální znevýhodnění žáků představuje ve vzdělávacím systému ČR již řadu let poměrně obtížně diagnostikovatelný fenomén. Současná školská legislativa neposkytuje téměř žádná vodítka pro identifikaci žáků, jejichž speciální vzdělávací potřeby vyplývají z odlišného sociálního zázemí. Školský zákon (zákon č. 561/2004 Sb., ve znění pozdějších novelizací, \$16) pouze konstatuje, že školy a školská zařízení by měly poskytovat podpůrná opatření odpovídající „kulturnímu prostředí nebo jiným životním podmínkám dítěte, žáka nebo studenta“; vyhláška o vzdělávání žáků se speciálními vzdělávacími potřebami (vyhláška č. 27/2016 Sb., ve znění pozdějších novelizací) pak ve výčtu podpůrných opatření zmiňuje i skupinu „„̌áků s potřebou podpory ve vzdělávání z důvodu odlišných kulturních a životních podmínek“.

Jak ale v praxi sociální znevýhodnění žáka určit? Co to jsou odlišné kulturní a životní podmínky? Kde jsou hranice normy a kde začíná znevýhodnění, které vyplývá z odlišností v domácím zázemí žáka? A jak 
takové znevýhodnění zohlednit v nastavení podpůnných opatření? Tyto otázky zůstávají velmi aktuálními v praxi škol i v každodenní realitě školských poradenských zařízení.

Následující text se proto: a) soustředí na zkušenosti s fenoménem sociálního znevýhodnění žáků a jeho diagnostikou v praxi pedagogicko-psychologických poraden; b) snaží na základě údajů od pracovníků PPP upřesnit, kde mohou být v praxi slabá místa v procesu diagnostiky sociálního znevýhodnění žáků.

Současný stav poznání

O vymezení fenoménu sociálního znevýhodnění žáků se v poslední dekádě pokouší odborná literatura (Habrová, 2015; Lábusová, 2015; Němec, 2019), která do kategorie žáků se sociálním znevýhodněním zařazuje zejména:

žáky s nedostatečnou podporou ve vzdělávání ze strany jejich rodičů;

- ̌̌áky s nedostatečnou znalostí vyučovacího jazyka;

- žáky, jejich rodiče nespolupracují se školou a vytvářejí tím bariéru ve vzdělávání žáka;

- ̌̌áky, jejichž rodinná socio-ekonomická situace je tak kritická, že se negativně projevuje ve vzdělávání dítěte;

žáky, u kterých kultura rodinného prostředí není souladu s kulturou školy;

žáky z dysfunkčních rodin a žáky umístěné v náhradní rodinné péči nebo v ústavní výchově;

žáky ze sociálně vyloučených lokalit.

Na úrovni přesných čísel dosud zůstává systémem nezodpovězená otázka, kolik dětí a žáků se sociálním znevýhodněním může v ČR být. K dispozici jsou ale dílčí statistiky, které celkové počty alespoň naznačují a identifikují například: šest a půl tisíce dětí žijících v zařízeních pro výkon ústavní a ochranné výchovy (MŠMTa, online, cit. 2021-05-23), sedm a půl tisíce dětí registrovaných jako týraných, zneužívaných nebo zanedbávaných (MPSV, 2021), více než dvacet tisíc dětí žijících v náhradní rodinné péči (MPSV, 2021), dvacet osm tisíc dětí - cizinců docházejících do základních škol (MŠMTb, online, cit. 2021-05-23), nebo čtyřicet až padesát tisíc dětí žijících v sociálně vyloučených lokalitách (MPSV, GAC, 2015). 0 kvalifikovaný odhad celkového počtu žáků se sociálním znevýhodněním se v minulosti pokoušeli autoři studie zpracované Univerzitou Palackého v Olomouci a obecně prospěšnou společností Clověk v tísni (Kolektiv autorů, 2015), kteří na základě kombinace různých dat a ukazatelů došli k závěru, že ve vzdělávacím systému ČR by mohlo být přibližně 140 tisíc žáků se sociálním znevýhodněním, a z toho u 35 tisíc žáků odhadovali znevýhodnění natolik závažné, že by mělo být důvodem pro diagnostiku ve školském poradenském zařízení a následné doporučení podpůrných opatření druhého nebo vyššśiho stupně.

Vztáhneme-li uvedené statistiky a odhady ke stávající poradenské praxi, ukazuje se diagnostika prováděná poradenským systémem jako velmi nedostatečná. Např́klad v roce 2020 uváděla statistická ročenka školství, že ve školských poradenských zařízeních bylo s výsledkem „žák s potřebou podpory ve vzdělávání z důvodu odlišných kulturních a životních podmínek“ diagnostikováno 17273 žáků (MŠMTc, online, cit. 2021-05-23) - i kdyby všem těmto žákům byl doporučen druhý nebo vyššś stupeň podpůrných opatření, ve srovnání s výše uvedenými kvalifikovanými odhady Univerzity Palackého a ČvT se stále jedná o necelou polovinu reálně znevýhodněných žáků. Více než polovina sociálně znevýhodněných žáků tak zůstává bez diagnostiky, a tedy i bez potřebné podpory...

Následující text popisuje průběh a výsledky výzkumného šetření, jehož cílem bylo specifikovat některé nedostatky, které v praxi poradenského systému vedou k nedostatečné identifikaci žáků se sociálním znevýhodněním a jejich vzdělávacích potřeb.

\section{Metoda a výzkumný vzorek}

Šetření bylo realizováno v rámci výzkumného projektu „Sociální znevýhodnění v procesu diagnostiky“, data byla sbírána během 22 dnů v průběhu května 2021. Ke sběru dat byla využita metoda online dotazníku, vytvořeného autory výzkumu a dostupného v aplikaci společnosti Survio. Dotazník měl poměrně pevnou strukturu kombinující uzavřené a polouzavřené otázky, celkově se skládal z jedenadvaceti otázek, z nichž první čtyři otázky byly demografického charakteru, dalších čtrnáct otázek se zaměřovalo na specifické oblasti tématu výzkumu², jedna otázka umožňovala účastníkům šetření libovolné doplnění názoru ke zkoumanému tématu a poslední dvě dobrovolné otázky dávaly prostor pro vyjádření zájmu o potenciální participaci na budoucím podrobnějším kvalitativním výzkumu ke zkoumanému fenoménu. Při tvorbě dotazníku byla velká pozornost věnována zejména náležitostem zvyšujícím návratnost dotazníku, mezi

2 Z toho poslední čtyři otázky byly zaměřeny na kulturní zatíženost standardizovaných testových materiálů a na vnímání souvislostí mezi sociálním znevýhodněním a vybranými diagnózami zdravotního postižení (poruchami učení, mentálním postižením, poruchami chování) - vzhledem k obsahové náročnosti nejsou výsledky odpovědí na tyto otázky součástí tohoto textu. 
které patří přehledné vizuální zpracování, přiměřené délka a celková uživatelská vstřícnost dotazníku (Reichel, 2009). Úvod do dotazníku obsahoval stručné upřesnění zaměření výzkumu, specifikaci časové náročnosti, která byla předpokládaná ve výši maximálně 15 minut, a poděkování za účast ve výzkumu. Hned v úvodu dotazníku byli účastníci informováni také o anonymitě zpracování dat, která byla garantována autory výzkumu.

Pro potřeby výzkumu autoři vyhledali na webu e-mailové kontakty na 46 pedagogicko-psychologických poraden evidovaných ve školském rejstř́ku MŠMT, jednotlivé poradny pak oslovili e-mailem s prosbou o participaci na výzkumu; oslovující e-mail byl směřovaný jak na obecné adresy poradenských pracovišt', tak i na adresy jednotlivých poradenských pracovníků.

Na základě výzvy autorů se do dotazníkového šetření zapojilo 176 pracovníků školských poradenských zařízení ze všech čtrnácti krajů ČR, nejvíce respondentů bylo z hlavního města Prahy (25 účastníků), nejméně respondentů bylo z Plzeňského kraje ( 4 účastníci) a z Pardubického kraje (4 účastníci). Velká většina účastníků výzkumu, konkrétně 171 respondentů, byla zaměstnána v pedagogicko-psychologických poradnách, pouze 5 respondentů bylo z řad zaměstnanců speciálně-pedagogických center. Nejčastěji byli mezi respondenty zastoupeni speciální pedagogové (88 účastníků), o něco méně často pak psychologové (78 účastníků), jen tři respondenti byli z řad sociálních pracovníků a zbývající čtyři respondenti uvedli jako svou primární pozici bud’ „ředitel“ nebo „metodik prevence“. Většina respondentů výzkumu uvedla poměrně rozsáhlou praxi v oboru - 31,3 \% respondentů uvedlo praxi v rozmezí deseti až dvacet let, 22,7\% respondentů mělo praxi od dvou do pěti let, 21 \% uvedlo praxi v rozsahu více než dvacet let, 17,6\% respondentů mělo praxi mezi pěti a deseti lety, a jen 7,4 \% respondentů uvedlo praxi kratší než dva roky.

Získaná data byla dále zpracována formou prosté analýzy číselných výsledků výzkumu a jejich př́ipadných slovních doplnění. Vzhledem ke složení výzkumného vzorku autoři výzkumu věnovali pozornost primárně pouze celkovým výsledkům v odpovědích na jednotlivé otázky výzkumu, při sekundární analýze se ale také zaměřili na specifika dílčích výsledků z regionů s vyšším zastoupením žáků s odlišným mateřským jazykem (Praha, Jihomoravský kraj) a z regionů s vyšším zastoupením žáků ze sociálně vyloučených lokalit (Ústecký a Moravskoslezský kraj).

\section{Výsledky šetření}

První dvě otázky dotazníku sledovaly, jak respondenti vnímají legislativní vymezení sociálního znevýhodnění, resp. - při použití stávající oficiální terminologie - jak vnímají legislativní vymezení kategorie „žáků s potřebou podpory ve vzdělávání z důvodu odlišných kulturních a životních podmínek“, a jak vnímají četnost zastoupení této skupiny mezi diagnostikovanými dětmi a žáky.

Odpovědi respondentů zde jasně ukázaly, že vymezení skupiny žáků se sociálním znevýhodněním v legislativě je nedostatečné a pro praxi špatně uchopitelné - většina respondentů (72,7\%) uvedla, že identifikace této žákovské skupiny podle zákona a vyhlášky neníjasná a že v praxi je složité určit, kdo a na základěčeho

\begin{tabular}{|c|c|c|}
\hline Možnosti odpovêdí & Responzi & Podil \\
\hline - a) Identifikace této zákovské skupiny podle zákona a whlásky je jasná, pro praxi dobie uchopitelná. & 32 & $18,2 \%$ \\
\hline $\begin{array}{l}\text { b) Identifikace této zákovské skupiny podle zákona a whlášky neni zela jasná, v praxi je sloz̄té určit, kdo a na základê } \\
\text { Ceho do této skupiny patrí. }\end{array}$ & 128 & $72,7 \%$ \\
\hline $\begin{array}{l}\text { c) Identifikace této zảkovské skupiny podle zákona a whllašky je absolutné nejasná, v praxi se vủbec nedá určit, kdo a } \\
\text { na základé ceho do této skupiny patî̉. }\end{array}$ & 10 & $5,7 \%$ \\
\hline d) Jiné - prosim doplinte: & 6 & $3,4 \%$ \\
\hline
\end{tabular}

do dané skupiny má patřit.

Tab. 1. Odpovědi na otázku: Jak hodnotíte pojetí „žáků s potřebou podpory ve vzdělávání z důvodu odlišných kulturních a životních podmínek“ v podobě, ve které s touto kategorií pracuje školský zákon a vyhláška (č. 27|2016 Sb., o vzdělávání žáků se speciálními vzdělávacími potřebami)?

V navazující otázce pak sice většina respondentů (63,1 \%) uvedla, že se se skupinou „žáků s potřebou podpory ve vzdělávání z důvodu odlišných kulturních a životních podmínek“ setkávají v praxi relativně často a že četnost diagnostiky tak zhruba odpovídá frekvenci výskytu těchto dětí v žákovské populaci, na druhou stranu ale přibližně třetina respondentů (34,1 \%) uvedla opak - tedy že se s danou skupinou žáků setkávají 
v poradenské praxi poměrně zřídka a že četnost diagnostiky je tedy z jejich pohledu nižší, než by odpovídalo frekvenci výskytu těchto dětí v žákovské populaci. Přibližně každý třetí pracovník poradenských zařízení tedy vnímá, že sociální znevýhodnění a z něj vyplývající vzdělávací potřeby jsou u žáků identifikovány nedostatečně. Zajímavé je, že toto podcenění diagnostiky sociálního znevýhodnění o něco více uváděli poradenští pracovníci z Prahy (44%) a z Jihomoravského kraje (47\%), tedy z krajů s vyšším výskytem žáků-cizinců; disproporce mezi skutečným počtem žáků a počtem diagnostikovaných žáků je tedy zřejmě patrná zejména u žáků s odlišným mateřským jazykem.

Další část dotazníku se zaměřovala na nástroje a metody, které mají poradenská zařízení k dispozici pro určování speciálních vzdělávacích potřeb žáků se sociálním znevýhodněním, přičemž i zde se ukázaly některé zřetelné nedostatky. Velká většina (74,4 \%) poradenských pracovníků například uvedla, že v praxi nedisponují vůbec žádnými metodickými materiály, které by jim pomáhaly při identifikaci „žáků s potřebou podpory ve vzdělávání z důvodu odlišných kulturních a životních podmínek“.

\begin{tabular}{|l|c|c|}
\hline Možnosti odpovédi & Responzí & Podil \\
\hline a) ano - prosim uveđte, o jaké materiály se jedná (stači název materiálu nebo jméno autora): & 45 & $25,6 \%$ \\
\hline b) ne, żảdné takové materiály k dispożci nemáme & 131 & $74,4 \%$ \\
\hline
\end{tabular}

Tab. 2. Odpovědi na otázku: Máte k dispozici jakékoli metodické materiály, které by Vám pomáhaly v identifikaci „žáků s potřebou podpory ve vzdělávání z důvodu odlišných kulturních a životních podmínek“?

Jen přibližně čtvrtina respondentů uvedla, že v praxi disponují nějakým metodickým materiálem pro identifikaci sociálního znevýhodnění žáků, přičemž ovšem nejčastěji šlo o materiály specificky zaměřené na diagnostiku žáků s odlišným mateřským jazykem - konkrétně 29 respondentů v této souvislosti zmínilo materiály vydané obecně prospěšnou společností Meta a dalších 8 respondentů uvedlo materiály pro práci s žáky-cizinci od Národního ústavu pro vzdělávání (resp. od Národního pedagogického institutu); pouze 5 respondentů pak uvedlo, že pracují s Katalogem podpůrných opatření (dílčí částí zaměřenou na podporu žáků se sociálním znevýhodněním) vydaným Univerzitou Palackého v Olomouci, jakékoli další materiály pak byly zmiňovány už jen zcela ojediněle.

Jen menšina poradenských pracovníků se při identifikaci vzdělávacích potřeb sociálně znevýhodněných žáků může spolehnout na pomoc sociálního pracovníka - téměř třetina (31,3\%) respondentů v šetření uvedla, že pracovní úvazek jejich sociálního pracovníka je pro tyto potřeby nedostatečný, a další třetina (33,5 \%) respondentů ve výzkumu konstatovala, že pozici sociálního pracovníka v poradenském zařízení vůbec nemají.

\begin{tabular}{|c|c|c|}
\hline Možnosti odpovědi & Responzi & Podil \\
\hline - a) Ano, pożci sociálniho praconnika žizenou máme a rozah jeho úvažxu je dostatečný. & 62 & $35,2 \%$ \\
\hline b) Ano, pożci sociálniho praconnika žizenou máme, ale rozah jeho úvazu je nedostačujici. & 55 & $31,3 \%$ \\
\hline c) Ne, pażci sociálniho pracomila v našem zariżeni żizenou nemáme. & 59 & $33,5 \%$ \\
\hline
\end{tabular}

Tab. 3. Odpovědi na otázku: Máte ve Vašem poradenském zařízení pozici sociálního pracovníka? A pokud ano, je jeho úvazek dostatečný (tak, aby pokryl potřeby vyplývající z práce s „žáky s potřebou podpory z důvodu odlišných kulturních a životních podmínek“)?

Drobným pozitivním zjištěním je o něco lepší hodnocení přítomnost sociálního pracovníka v regionech s vysokým výskytem sociálně vyloučených lokalit - v Ústeckém kraji téměř polovina a v Moravskoslezském kraji dokonce nadpoloviční většina respondentů hodnotila úvazek sociální pracovníka jako dostatečný.

Na druhou stranu ale několik respondentů k pozici sociálního pracovníka v závěru výzkumu (ve volné otázce) doplnilo, že pozice sice v jejich zařízení zř́́zena je, ale že je využívána převážně na administrativní agendu - jak komentoval jeden z respondentů: „Sociální pracovnice v PPP je zavalena prací administrativně-ekonomickou a na sociální práci nemá žádný čas." 
Pro sběr údajů potřebných k identifikaci sociálního znevýhodnění žáka, resp. k identifikaci jeho vzdělávacích potřeb vyplývajících „z odlišných kulturních a životních podmínek“, většina poradenských pracovníků využívá anamnestický rozhovor se zákonným zástupcem dítěte (94,9% respondentů) a informace poskytnuté školou, kterou žák navštěvuje (91,5 \% respondentů).

\begin{tabular}{|c|c|c|}
\hline Možnosti odpovědi & Responzi & Podil \\
\hline - a) Cas na rozhovor je zcela dostačujicí & 65 & $36,9 \%$ \\
\hline - b) Eas na rożovor je vêtsinou dostacujici, nékdy bych ale ocenil/a vice casu & 92 & $52,3 \%$ \\
\hline - c) Ċas na rothovor je spiše nedostačujici, ve vétšinẻ prijpadà by byla vhodnējši delsí ċasová dotace & 14 & $8,0 \%$ \\
\hline 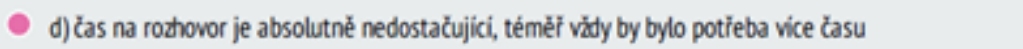 & 5 & $2,8 \%$ \\
\hline
\end{tabular}

Tab. 4. Odpovědi na otázku: Jaké zdroje informací využíváte pro získávání údajů potřebných k identifikaci vzdělávacích potřeb vyplývajících z odlišných kulturních a životních podmínek dítěte?

Jen necelá třetina respondentů (30,7 \%) uvedla, že kromě rozhovoru se zákonnými zástupci a zpráv od školy získávají informace o případném sociálním znevýhodnění žáka také z jiných zdrojů - zde poradenští pracovníci nejčastěji uváděli informace od OSPOD, dále pak informace získané ve spolupráci s dětskými domovy, středisky výchovné péče, místními poskytovateli sociálních služeb (azylový dům, SAS), Člověkem v tísni a dalšími neziskovými organizacemi, pediatry, psychiatry a dalšími lékaři; z doplňkových diagnostických metod pak také zmiňovali rozhovor s dítětem, testy od Meta o.p.s. a pozorování žáka v hodině.

U anamnestického rozhovoru se zákonnými zástupci a získávání informací od školy - tedy u dvou nejběžnějších zdrojů dat potřebných pro identifikaci sociálního znevýhodnění žáka - se výzkumné šetření dále také zaměřovalo na rozsah časových dispozic, které mohou poradenští pracovníci těmto zdrojům dat věnovat, a na to, zda poradenští pracovníci hodnotí rozsah času na využití těchto zdrojů dat jako dostatečný.

Anamnestickému rozhovoru se zákonnými zástupci žáků může většina (58,5 \%) respondentů věnovat patnáct až třicet minut, další téměř pětina (18,8 \%) respondentů má na takový rozhovor k dispozici třicet až pětačtyřicet minut. Jen poměrně malá část (6,3 \%) respondentů uvedla, že má na rozhovor s rodiči diagnostikovaného žáka k dispozici méně než patnáct minut.

\begin{tabular}{|c|c|c|}
\hline Možnosti odpovêdi & Responzi & Podil \\
\hline - a) zadný & 1 & $0,6 \%$ \\
\hline b) ménẻ než 15 minut (ale vice než "zädnỹ) & 26 & $14,8 \%$ \\
\hline c) 15 aż 30 minut & 102 & $58,0 \%$ \\
\hline d) 30 až 45 minut & 26 & $14,8 \%$ \\
\hline - e) 45 až 60 minut & 11 & $6,3 \%$ \\
\hline f) vice než 60 minut & 8 & $4,5 \%$ \\
\hline g) komunikaci se školami ajištuje jiný pracomik našeho zifizeni, otáza se mé tedy netyjká & 2 & $1,1 \%$ \\
\hline
\end{tabular}

Tab. 5. Odpovědi na otázku: Kolik času máte na anamnestický rozhovor se zákonným zástupcem žáka (v průměru na jednoho žáka)?

Časovou dotaci pro rozhovor ale hodnotí větší část poradenských pracovníků - z hlediska podrobné identifikace vzdělávacích potřeb žáků „z odlišných kulturních a životních podmínek“ - jako nedostatečnou. Ve více než polovině případů (52,3 \%) respondenti výzkumu uvedli, že by ale alespoň občas ocenili více času na rozhovor s rodiči žáka, menší část dotazovaných pak konstatovala, že více času na rozhovor by bylo potřeba ve většině případů (8,0 \% respondentů) nebo dokonce téměř vždy (2,8 \% respondentů). 


\begin{tabular}{|c|c|c|}
\hline Možnosti odpovédi & Responzi & Podil \\
\hline 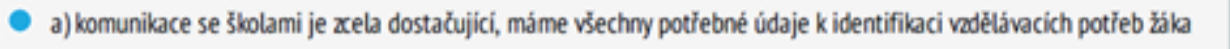 & 40 & $22,7 \%$ \\
\hline $\begin{array}{l}\text { b) komunikace se skolami je vétşinou dostačujici, nékdy by ale pomohlo, kdyby nám konkrétni škola poskytla vice } \\
\text { údajú k identifikaci vadélávacich potíeb žäka }\end{array}$ & 128 & $72,7 \%$ \\
\hline 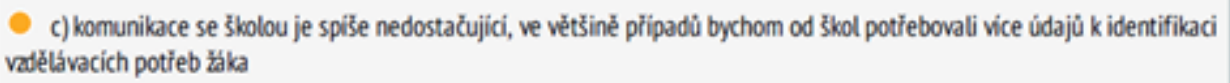 & 7 & $4,0 \%$ \\
\hline $\begin{array}{l}\text { d) komunikace se školou je absolutné nedostačujici, témér ve v̌ech pripadech by k efektivité diagnostiky pomohlo, } \\
\text { kdybychom od školy méli vice údajủ o z̈ăkovi }\end{array}$ & 1 & $0,6 \%$ \\
\hline
\end{tabular}

Tab. 6. Odpovědi na otázku: Jak hodnotíte rozsah času pro anamnestický rozhovor z hlediska zjištóvání vzdělávacích potřeb žákủ pocházejících z odlišných kulturních a životních podmínek?

Na komunikaci se školou, získávání a vyhodnocování dat o žákovi poskytnutých učiteli - druhý potencionálně přínos zdroj dat pro identifikaci sociálního znevýhodnění žáka - má většina (58,0 \%) respondentů výzkumu časovou dotaci v rozmezí patnácti až třiceti minut. Výrazně menší část poradenských pracovníků má na tuto aktivitu čas mezi třiceti a pětačtyřiceti minutami (14,8 \% respondentů), pro praxi ovšem rozhodně stojí za pozornost, že srovnatelně velká skupina poradenských pracovníků uvedla, že na získávání a vyhodnocování informací o žákovi ze školy má jen méně než patnáct minut (14,8% respondentů).

U respondentů, kteří uvádějí více času na rozhovor se zákonnými zástupci žáka a hodnotí čas na tento rozhovor jako dostatečný, je ovšem také otázka, nakolik tyto jejich výpovědi vyplývají z ochoty věnovat se své práci nad rámec placené pracovní doby - jak například uvedl jeden respondent v otevřené otázce v závěru výzkumu: „...času si udělám, kolik potřebuji, ale ,papíry“ pak chodím dělat v sobotu..."

\begin{tabular}{|c|c|c|}
\hline Molnosti odpoveldi & Responzi & Podil \\
\hline a) athy & 1 & $0,6 \mathrm{x}$ \\
\hline - b) nedel net 15 minst (ale vice net 'zadny') & 26 & $14,8 \%$ \\
\hline - c) 15 al 30 ming & 102 & $58,0 \%$ \\
\hline - ब) 30 at 45 mint & 26 & $14.8 \%$ \\
\hline - e) 45 ai 60 minut & 11 & 6,38 \\
\hline - f) vice nel 60 minut & 8 & $4,5 x$ \\
\hline 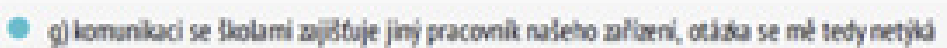 & 2 & $1,1 \%$ \\
\hline
\end{tabular}

Tab. 7. Odpovědi na otázku: Kolik času máte na komunikaci se školou - získávání a vyhodnocování údajů o žákovi od učitelů (v průměru na jednoho žáka)?

I v oblasti komunikace se školami spatřují poradenští pracovníci určitý nevyužitý potenciál pro sběr důležitých diagnostických dat - velká většina respondentů (72,7 \%) ve výzkumu uvedla, že alespoň v některých případech by pomohlo, kdyby škola poskytla o žákovi více údajů k identifikaci vzdělávacích potřeb žáka. Podle menší skupiny účastníků výzkumu by pak více informací o žákovi ze školy bylo potřeba ve většině př́ípadů (4,0 \% respondentů). 


\begin{tabular}{|c|c|c|}
\hline Moknosti odpovldi & Respond & Podil \\
\hline - a) lomunikace se Selami je xela destabujki, mime vechny potietne udaje kidertifiadi valthacich potieb bla & 40 & $22,7 \%$ \\
\hline 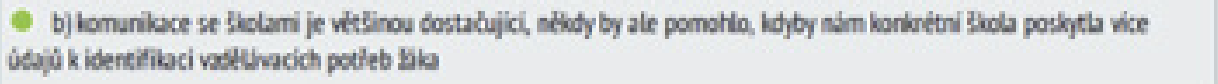 & 128 & $72,7 \%$ \\
\hline 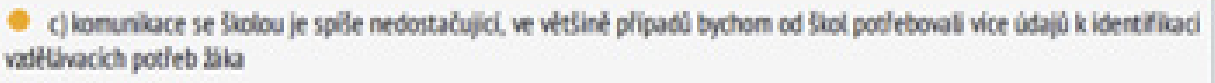 & 7 & 4,080 \\
\hline 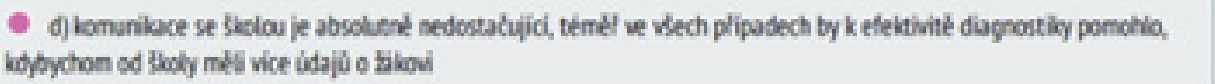 & 1 & 0,65 \\
\hline
\end{tabular}

Tab. 8. Odpovědi na otázku: Nakolik považujete komunikaci se školami v procesu diagnostiky za dostatečnou? A vyplývá z této komunikace dostatek informací pro identifikaci vzdělávacích potřeb, které u žáka mohou vznikat z důvodu odlišných kulturních a životních podmínek?

Řadu zajímavých postřehů vztahujících se k možnému zefektivnění diagnostiky sociálně znevýhodněných žáků přinesla otevřená otázka uvedená v závěru dotazníku, která se respondentů ptala: „Co by, podle Vašich zkušeností, pomohlo ke zefektivnění diagnostiky vzdělávacích potřeb vyplývajících z odlišných kulturních a životních podmínek dítěte?“ Odpovědi na tuto otázky byly poměrně různorodé, častěji se ale mezi nimi objevovaly požadavky na:

a) vytvoření přehledné metodiky pro identifikaci sociálního znevýhodnění, s jasným vymezením dané kategorie žáků; b) vytvoření screeningového diagnostického materiálu určujícího míru sociálního znevýhodnění; c) zlepšení spolupráce s OSPOD/sociálními službami v oblasti získávání informací o dítěti;

jak ve své odpovědi uvedl jeden z respondentů, pomohla by: „...jasná a jednotná definice, jednoduchý screeningový dotazník, na základě kterého by se mohl domluvit delší rozhovor se sociální pracovnicí, která by měla prostor více komunikovat i s návaznými sociálními službami (samozřejmě ruku v ruce s navýšením úvazku soc. prac.)...";

dále respondenti uváděli, že by pomohlo d) více času na vyšetření:

„.... minimálně možnost věnovat anamnéze výše uvedenou hodinu ,legálně‘ a ne na úkor svého volného času. Časy vypočítané na standardní vyšetření jsou (nejen v př́ípadě žákủ z těchto skupin) nereálné, zaberou času daleko více...";

a také e) větší prostor pro spolupráci se školou, a f) lepší screening sociálního znevýhodnění už ve škole:

„...více času na komunikaci se školou a metodickou podporu školám, sledování žáků při vyučování...“

„....podle mého pokud by na školách bylo více školních psychologů, kteří by nám pomohli takové žáky najít a předali erudovanější informace a následně by také s těmito dětmi mohli na škole pracovat..."

u žáků s odlišným mateřským jazykem by pak podle respondentů výzkumu pomohla také g) důkladnější jazyková příprava žáků, a h) snazší přístup ke službám tlumočníků:

„...jazyková příprava těchto žákủ pred vstupem do základního školství, a to i do vyšších ročníkủ..."

„....snadnější př́istup ke kvalifikovaným překladatelơm, zejména z vietnamštiny.“

\section{Shrnutí hlavních zjištění, diskuse}

V celkovém pohledu prezentované výzkumné šetření zaměřené na vybrané praktické aspekty diagnostiky sociálního znevýhodnění žáků dospělo k těmto hlavním zjištěním:

A. Sociální znevýhodnění, resp. znevýhodnění vyplývající z „odlišných kulturních a životních podmínek“, představuje jen velmi neurčitý koncept, pro pracovníky školských poradenských zařízení je tak obtížné určit, kdo a na základě čeho do této skupiny žáků má patřit.

B. V praxi školských poradenských zařízení chybí metodické materiály, které by byly využitelné při identifikaci sociálního znevýhodnění/odlišných kulturních a životních podmínek žáků.

C. Pozice sociálního pracovníka, která by mohla být pro identifikaci sociálního znevýhodnění žáků klíčová, je ve většině poradenských zařízení personálně poddimenzována, a nepředstavuje tak pro proces diagnostiky očekávaný přínos.

D. V práci psychologů a speciálních pedagogů představují klíčové nástroje sběru dat pro identifikaci sociálního znevýhodnění anamnestický rozhovor s rodiči žáka a analýza informací poskytnutých školou, do které žák dochází. Při využití obou těchto nástrojů ale poradenští pracovníci narážejí na nedostatečné 
kapacity a nadměrné zatížení poradenského systému - alespoň občas by pracovníci poraden potřebovali více času na anamnestický rozhovor s rodiči nebo větší prostor pro získávání informací od školy, vzhledem k velkému množství klientů poradenského systému ale potřebné volné kapacity pro tyto činnosti nemají.

Uvedené bariéry a nedostatky v diagnostice sociálního znevýhodnění korespondují se současným stavem poznání, ve kterém odborná literatura poukazuje na obtížnost uchopení konceptu sociálního znevýhodnění pro praxi (Habrová, 2015; Němec, 2019), a poskytují určité základní vysvětlení pro disproporce mezi odhadovaným počtem sociálně znevýhodněných žáků (Kolektiv autorů, 2015) a významně nižším počtem žáků skutečně diagnostikovaných v dané kategorii (MŠMTc, online, cit. 2021-05-23).

\section{Doporučení pro praxi, závěr}

Z uvedených dat a hlavních zjištění výzkumu vyplývají zejména tato doporučení pro další systémové zefektivnění poradenské praxe u žáků se sociálním znevýhodněním:

1. Upřesnit koncept sociálního znevýhodnění/odlišných kulturních a životních podmínek na legislativní úrovni.

2. Vypracovat jednoduchou a přehlednou metodiku a screeningový test, určené pro základní identifikaci sociálního znevýhodnění žáků.

3. Výrazně posílit počty sociálních pracovníků (nebo sociálních pedagogů) ve školských poradenských zařízeních a poskytnout těmto pracovníkům metodické vedení v oblasti identifikace vzdělávacích potřeb vyplývajících z odlišného kulturních a životního prostředí žáků.

4. Výrazně posílit personální kapacity poradenského systému - v řadách speciálních pedagogů a psychologů - tak, aby odborní pracovníci měli více času na diagnostiku žáka ${ }^{3}$, včetně větší časové dotace na anamnestický rozhovor se zákonnými zástupci žáka.

5. Podporovat zefektivnění komunikace mezi školskými poradenskými zařízeními a školami, případně také dalšími relevantními institucemi (OSPOD, NNO, organizace poskytující sociální služby), například prostřednictvím systémového nastavení této komunikace do role sociálních pracovníků nebo sociálních pedagogů ve školách i ve školských poradenských zařízeních.

Závěrem je potřeba zdůraznit, že uvedená doporučení nemají za cíl pouze identifikovat a nastavit podporu pro určitou skupinu žáki̊, nýbrž, v obecnějším pohledu, směřují k zefektivnění celého vzdělávacího systému. Žáci se sociálním znevýhodněním představují ve školství poměrně početnou skupinu a zdokonalení jejich diagnostiky, které povede k lepšímu nastavení podpůrných opatření pro tyto žáky, pomůže i jejich učitelům, kteří tak budou mít lepší výchozí podmínky pro práci s celými žákovskými kolektivy.

Hlavními limity výše popisovaného výzkumu jsou jeho převážně kvalitativní formát a omezených výzkumný vzorek. Získaná zjištění by tedy bylo vhodné dále rozvíjet navazujícími výzkumy, a to jak s kvantitativní orientací - na více reprezentativním výzkumném vzorku, tak i s orientací kvalitativní - u vybraných témat více do hloubky.

\section{Literatura}

FELCMANOVÁ, L. (2015) Pedagogická diagnostika žáka, který potřebuje podporu z důvodu sociálního znevýhodnění. In FELCMANOVÁ, L. HABROVÁ, M. a kol. Katalog podpůrných opatření, dílčí část pro žáky s potřebou podpory ve vzdělávání z důvodu sociálního znevǵhodnění. Olomouc: Univerzita Palackého v Olomouci, 2015. str. 19-24.

HABROVÁ, M. (2015) Definice sociálního znevýhodnění. In FELCMANOVÁ, L. HABROVÁ, M. a kol. Katalog podpưrných opatření, dílčí část pro žáky s potřebou podpory ve vzdělávání z dưvodu sociálního znevýhodnění. Olomouc: Univerzita Palackého v Olomouci, 2015. str. 8-10.

KOLEKTIV AUTORŮ (2015). Očekávané rozložení četnosti SVP podle stupňuo podpůrných opatření. Výstup projektu „Systémová podpora inkluzivního vzdělávání v CR“. Olomouc: Univerzita Palackého v Olomouci. Dostupné z: http://www.inkluze.upol.cz/portal/vystupy/

LÁBUSOVÁ, A. (2015) Projevy sociálního znevýhodnění a jeho dopady do vzdělávání. In FELCMANOVÁ, L. HABROVÁ, M. a kol. Katalog podpưrných opatření, dílčí část pro žáky s potřebou podpory ve vzdělávání z dưvodu sociálního znevýhodnění. Olomouc: Univerzita Palackého v Olomouci, 2015. str. 11-18.

3 Větš́ časová dotace na dítě/žáka by mohla pracovníkům školských poradenských zařízení pomoci také k většímu zapojení metod dynamické diagnostiky, která monitoruje dopady poskytnuté intervence a přesněji zachycuje potenciál rozvoje žáka (Felcmanová, 2015). 
MPSV (2021). Roční výkaz o výkonu sociálně právní ochrany dětí za rok 2020. Praha: Ministerstvo práce a sociálních věcí ČR. Dostupné z: https://www.mpsv.cz/web/cz/statistiky-1

MPSV, GAC (2015) Výskyt sociálně vyloučených lokalit v ČR a podle krajů. MPSV a GAC spol. s.r.o. Dostupné z: https://www.esfcr.cz/mapa-svl-2015/www/index9ba9.html?page=3

MŠMTa (online, cit. 2021-05-23) tab. „H1.2.1 Zařízení pro výkon ústavní výchovy a ochranné výchovy děti a mládež podle věku - podle zařízení a území“ In: Statistická ročenka školstuí - výkonové ukazatele školního roku 2020/2021. Praha: MŠMT ČR. Dostupné z: https://statis.msmt.cz/rocenka/rocenka.asp

MŠMTb (online, cit. 2021-05-23) tab. „C1.10 Základní vzdělávání - žáci/dívky, cizinci podle druhu pobytu podle státního občanství“ In: Statistická ročenka školství - výkonové ukazatele školního roku 2020/2021. Praha: MŠMT ČR. Dostupné z: https://statis.msmt.cz/rocenka/rocenka.asp

MSMTc (online, cit. 2021-05-23) tab. „C1.31.1 Základní vzdělávání - žáci se SVP, nadaní a žáci s přiznaným PO s kódem NFN, z toho dívky - podle území“ In: Statistická ročenka školství - výkonové ukazatele školního roku 2020/2021. Praha: MSMT ČR. Dostupné z: https://statis.msmt.cz/rocenka/rocenka.asp

NĚMEC, Z. a kol. (2019) Systematická podpora sociálně znevýhodněných žáků ve vzdělávání. Praha: Nová škola o.p.s.

REICHEL, J. (2009) Kapitoly metodologie sociálních výzkumů. Praha: Grada Publishing.

Vyhláška č. 27/2016 Sb., o vzdělávání žáků se speciálními vzdělávacími potřebami a žákủ nadaných, ve znění pozdějších novelizací.

Zákon č. 561/2004 Sb., o předškolním, základním, středním, vyšším odborném ajiném vzdělávání (školský zákon), ve znění pozdèjších novelizací.

\section{Informace o autorech}

PhDr. Zbyněk Němec, Ph.D.

Speciální pedagog, vyučující na katedře speciální pedagogiky Pedagogické fakulty Univerzity Karlova.

Email: zbynek.nemec@pedf.cuni.cz

URL: https://www.researchgate.net/profile/Zbynek-Nemec

\section{Mgr. Tereza Philippová}

Speciální pedagog, pracovnice Pedagogicko-psychologické poradny pro Prahu 3 a 9.

Email: tereza.philippova@ppp3a9.cz 